\title{
ГЕПАТОПРОТЕКТОРНОЕ ДЕЙСТВИЕ ЛЕКАРСТВЕННОГО СРЕДСТВА НА ОСНОВЕ ЦИКОРИЯ ОБЫКНОВЕННОГО (CICHORIUM INTYBUS L.)
}

\author{
С.В. Лемясева, А.Н. Бабенко, Л.В. Крепкова \\ ФГБНУ «Всероссийский научно-исследовательский институт лекарственных \\ и ароматических растений», 117216, Россия, г. Москва, ул. Грина, д. 7.
}

DOI: 10.19163/MedChemRussia2021-2021-150_E-mail: lemyaseva.svetlana@yandex.ru

В настоящее время большинство применяемых в медицине лекарственных средств для лечения и профилактики заболеваний печени, представляют препараты растительного происхождения, в химический состав которых входят фенольные соединения. Перспективным источником получения биологически активных веществ фенольной природы является цикорий обыкновенный (Cichorium intybus L.) семейства астровые (Asteraceae), который имеет широкий ареал произрастания на территории России, что обеспечивает его стабильную сырьевую базу [1]. В ФГБНУ ВИЛАР из травы цикория обыкновенного получен экстракт сухой (ЦОТЭС), химический состав которого представлен преимущественно фенолкарбоновыми кислотами, флавоноидами, оксикумаринами. Целью нашего исследования являлось изучение антигепатотоксического действия ЦОТЭС на экспериментальной модель острого токсического гепатита у крыс, вызванного однократным подкожным введением сулемы (хлорид ртути (II) в дозе 3 мг/кг). ЦОТЭС вводили в желудок крысам в дозах 100 и 500 мг/кг, Силимар ${ }^{\circledR}$ (препарат сравнения) - в дозе 100 мг/кг, профилактически в течение 20 дней.

Под влиянием сулемы отмечалось токсическое повреждение печени, характеризующееся повышением активности аланин- (АлТА) и аспартаттрансаминаз, щелочной фосфатазы, гамма-глутамилтрансферазы в сыворотке крови, увеличением массы печени и наличием гиалиново-капельной дистрофии гепатоцитов. Введение ЦОТЭС в обеих дозах снижало активность указанных ферментов сыворотки крови: активность АлТА снижалась с 126,3 44,1

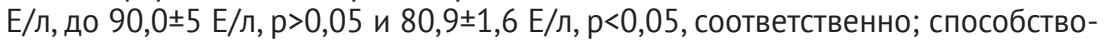
вало сохранению относительной массы печени и регенерации гепатоцитов. Более выраженными эти изменения были у животных, получавших максимальную дозу 500 мг/кг. По эффективности гепатопротекторного действия на указанной модели патологии ЦОТЭС в дозе 100 мг/кг соответствовал препарату Силимар ${ }^{\circledR}$, взятого в той же дозе.

Полученные результаты свидетельствуют о перспективности использования ЦОТЭС в качестве гепатопротекторного лекарственного средства.

\section{Литература}

[1] О.Л. Сайбель, Т.Д. Даргаева, К.А. Пупыкина, Изучение желчегонной и гепатопротекторной активности травы цикория обыкновенного, Медицинский вестник Башкортостана. 2015, Том 10, №5(59), С.72-75. 